\author{
GAP-FACT OR APPROACH ID MOUI-UY IFON \\ FIBLD AIR OAFB \\ BY
}

Dr. I.M. PARRAO

ABSTRACT:

Method to determine the eperkover voltage for varlous gap goometrioe io deacribed. The reaulte indicate that a numerical coeffloient of an empirical nature unch a gap factor can be dereloped.

\title{
ITTRODUCTION :
}

Gap-lactor 1a a numerical device whioh dearibe the Beonetery of any partlcular conflguration. Becauno of the time and expenae Inrolred ln high-roltage teate ou large atructurea, any method of axtrapolating the fom reaulta 1 eoonomically raluablo and of a conaiderable ald to doalgn. Phla powerful technique ha beof developed by Parlal. Leroy. Gallet, Konataluk, and Kromerc heve been suggented that, the experimental determinetion of the gap-fector for any oonfiguration at ono apaoing onables the veli-artabliahed rodplane data to be extrapolating for that configuration for other epacinge. Thia paper reporta experimenta for both poiltive lightining and awitchlag impulseg to represent the sparkover roltage of the alr gape by muerical calculation of the gep-factor for diforent geonetriaa, o.z. rod-plane, torold-plane, and ophereplane als gap conflgurations. The plane electrode was oarthed. Gap lengths of $150 \mathrm{~mm}, 300 \mathrm{~mm}$ mere attempted.

EXPERTMENTAC PROCEDURES

APEARATUS

A Bix-atage 1mpulse generator of max Imum output $330 \mathrm{kV}$ wa used to genergte both Ilghtning and owitching positive impulese (1.2/50 $\mathrm{s}$ and $60 / 2500 \mu \mathrm{s}$ impulge anepe reapectiv1ly). Gap lentins of $150 \mathrm{~mm}$ anc $300 \mathrm{~mm}$ ware attampted. The gap configurationg are a hemiapherically tippod rod of 19 diameter againat an earthed plano, a toroid of $30 \mathrm{~cm}$ dlaneter againat an earthed plane, and a shere of 75 mo dameter agelast an earthed plane. Sparkover probability measuremente were obtalned from 50-60 impulae at egch test voltaze level. Fig. 1, show the exparimental arrangemont for a rod-plane gap.

Suez Canal Univeralty, College of Eng1neering. Dept. of Electrical anglneering, Port - Sala. 
Gap-factor decreaen 1 th increesing divergence of the loctric lield distribution and increasen ith leareaning oonvergence a shom 1n Pigure 2 for both positlve 11 ghtaing ang

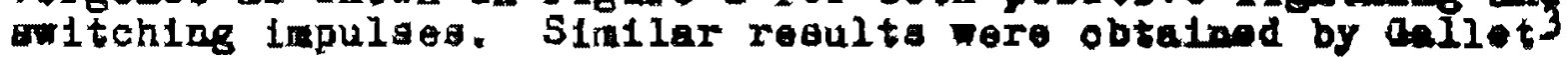
for gepe up to $10 \mathrm{~m}$. He showed experimentelly for rod-rod gape up to $10 \mathrm{~m}$ that, the gap-factor wae given bJ:

$$
k=1+0.6 \mathrm{~h} /(\mathrm{h}+\mathrm{d})
$$

There $x$ wa the gep-faotor, h wae the length of the earthed rod, and was the gap longth. Figure 2 , abor aluo thet, the mean sparkover gradiont increases linearly wth lnorealing the gap-factor. The Ilnear varlation of apacover gradient with gapfactor vas alao found for more complex otruoturea (Paria and Cortina ) Pariol (1967) propaed an eapirical formula for rodplene gape for poitive oritching impulaea was given by:

$$
Y_{a}=Q d^{n} \quad k Y\left(\operatorname{Par} 1 a^{1}\right)
$$

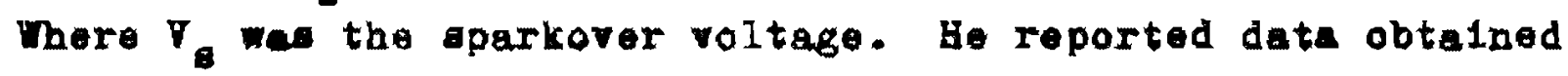
It h an impulae ahape $120 / 4000$ ps for longer gapa of up to 6. Bm length. The perametera $G$, and $n$ were 500 and 0.6 reapectivaly. Thea paranetere were 400 and 0.75 with great atiofeotlon with the experinental reaulta obtalned for the varloue gap conrlgurm atione under inveatigation. It we found from the rosult that; the ratio of the positive anttch1ng-impulae aparkover voltagea for diarimilar conflgurations was indopendent th the gap langth. By taking a base tho perkover voitage for the rod-plane gap contiguretion. which can be emplrically ropresented( \pm 5 terpor)by;

$$
v_{\mathbf{g}}=400 \mathrm{~d}^{0.75 \mathrm{kV}}
$$

for poative lightning impulsea and approrimately, aloo valid Por positive witehing impulas.

The aparkover voltage for ang other configuration ( $V_{g}$ ) cen be given by:

$$
v_{g}=400 \times \mathrm{d}^{0.75} \mathrm{kV}
$$

where $\mathrm{K}$ is the zap factor for that conflguration, and d is the gap length in meter. It is not posalble to determine the gapfactor from the electroatetic fleld datribution, or to relate it to the ohysical development of the discharge (some uaeful attempto have been made by Schneider and Weck5; and Garciabs.

\section{REFRRBDCES}

1. Paria, I. (1967). IEEE Trana. PASm86,936.

2. Leroy, G., Gallot, G.Kogztaluk, R, and Kromer, I ل. (1974). Rev. Gen. del Electrielté.

3. Gallet, G. (1974). BuI1. CIGRS Group 33, Vol. II.

4. Par1a, L, and Cortina, K. (1968), IEBE Trana. PAs-87,947. 5. Schneider, K.H. and Weois, K.H.(1974). Electra, No. 35, 25. 6. Garcla, $B . A .(1975)$. Int. Symp. Hochapannungatechnik, Zurich. 
Fig.(1) Test arrangerneat

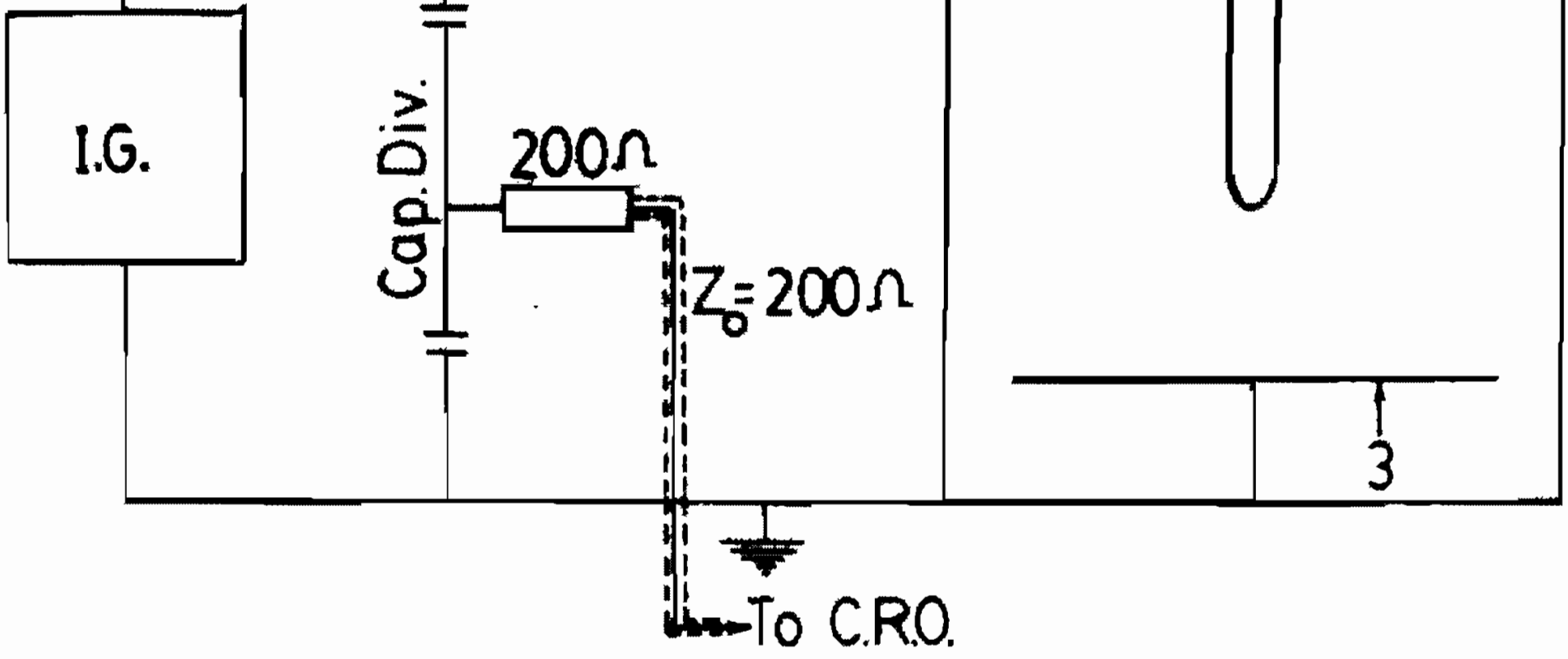

1 External wavefront resistor

2 High-vol tage electrode

3 Earthed plane electrode 


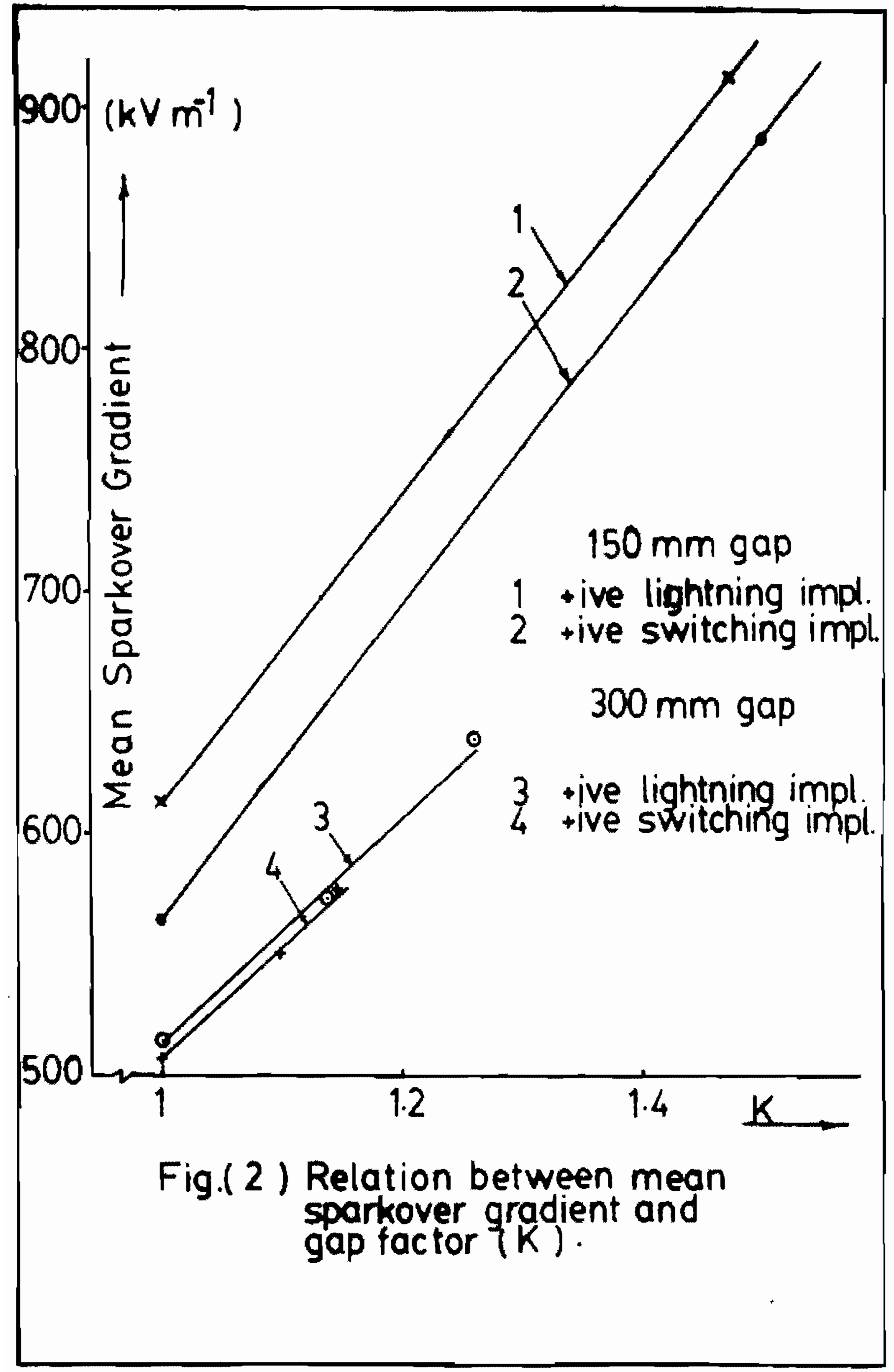

